原著

\title{
沖縄県に括ける $\mathrm{HBe}$ 抗原・抗体に関する疫学的研究
}

\begin{tabular}{llllll}
\multicolumn{9}{c}{ 琉球大学医学部第 1 内科 } & & \\
佐久川 廣 & 嘉手納啓三 & 親川 & 富憲 & 上原 & 正照 \\
新垣 民樹 & 金城 福則 & 小張 & 一峰 & &
\end{tabular}

(昭和61年 4 月 22 日受付)

(昭和61年 7 月 3 日受理)

Key words : $H B V, H B e A g$, anti-HBe, Seroconversion

要旨

沖縄県に抢ける HBV 感染の実態を調查する目的で, 妊婦を中心としたキャリアの HBe 抗原, 抗体系 の調査を実施した。

妊婦の HBs 抗原陽性率は $3.3 \%$ と高率であったが, これらキャリア妊婦における HBe 抗原陽性率は

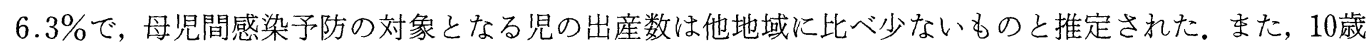
未満の小児で, HBs 抗原, 抗体陽性率がともに 1 \%前後と低率であったことより, 沖縄県に扔いては, 現在垂直感染，水平感染がともに急速に減少しているものと思われた。

一方, $\mathrm{HBV}$ キャリア全体の年齢別の HBe 抗原, 抗体の陽性率をみると, 10 歳未満では全例が $\mathrm{HBe}$ 抗 原陽性であるが, 年齢の上昇とともに陽性率が低下し, 10 代の後半から 20 代の前半にかけて陰転化のピ一 クを認め，30歳以上では，90\%以上のキャリアが seroconversionしていた。そして，このことは沖縄県 の慢性肝疾患の死亡率が低いことと関連しているものと思われた。

はじめに

1972年, Magnius \& Espmark ${ }^{11}$ にって HBe 抗原, 抗体系が発見されて以来多くの研究が重ね られ，その臨床的意義が明らかにされつつある。 殊に $\mathrm{Okada}^{2)} ら の$ 報告以来々の母児間感染に颃け る意義は重要なものとなった。

我々は，本邦に拀いて最も高いB型肝炎ウイル ス (以下 HBV) 保有率を示す沖縄県の妊婦を中心 としたキャリアについて, HBe 抗原, 拈よび HBe 抗体の調查を行った。 そして, 沖縄県の HBV 垂直 感染の現状と, キャリアにおける seroconversion に関し，他の地域と比較して興味のある成績を得 たので，それを報告するとともに若干の考察を加 壳てみた。

別刷請求先：（产903-01）沖縄県西原町字上原207 琉球大学医学部第 1 内科佐久川 廣

\section{対象及び方法}

1982年 6 月より 1983年 8 月までの期間に採取さ れた沖縄本島中部地区の妊婦検診受診者の血清 2,343 検体, ならびに1982年 1 月より 1983年12月ま での 2 年間に本島内の 3 ケ所の保健所の検診を受 けた20歳未満の年齢層の 905 検体について検討し た。をた，キャリアの血清として同期間内に県内 の与那城村, 渡嘉敷村, 粟国村, 南大東村の成入 病検診ならびに前記の保健所での検診時に発見さ れた HBs 抗原陽性者201例と前述の妊婦検診時 に見つかった64例の妊婦キャリア，あわせて265例 の $\mathrm{HBs}$ 抗原陽性血飞関して, $\mathrm{HBe}$ 抗原, 抗体系の 検討を行った。 また，これらのキャリアの家族調 査の時に得られたキャリアを発端者とするとの母 親の 29 血清も同時に今回の調査の対象に含めた (Fig. 1).

HBs 抗原の測定は RPHA 法, HBs 抗体の測定 
Fig. 1 Map of Ryukyu islands

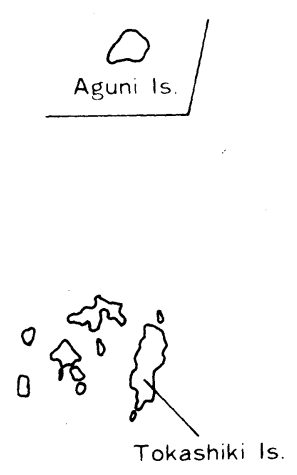

はPHA 法にてそれぞれ行った。また HBs 抗原陽 性の血清に対しては, 東京都臨床医学総合研究所 肝炎部門に依頼して，HBe 抗原，抗体の測定を EIA 法にて行った。

\section{成 績}

A. 妊婦に打ける HBV 抗原, 抗体系の調查 妊婦2,343例中, HBs 抗原陽性例は78例 (3.3\%) で，各年齢層間に有意差はなかった。また，HBs 抗体陽性例は 519 例 $(22.2 \%)$ で，これも年齢階級 別の比較で有意差をみなかった（Table 1).

$\mathrm{HBs}$ 抗原陽性 78例中, $\mathrm{HBe}$ 抗原, 抗体の検 索ができたのは64例で，そのうち 20 代後半の 4 例 $(6.3 \%)$ に $\mathrm{HBe}$ 抗原を認め，52例 $(81.3 \%)$ に $\mathrm{HBe}$ 抗体が検出された。抗原・抗体の陽性率とも に各年齢階級の相互間に有意差を認めなかった (Table 2).

B. 20歳未満の年齢層に打ける HBs 抗原，抗 体の陽性率

HBs 抗原の陽性率は905例中27例（3.0\%）で あった。年齢階級別の比較では，年齢が高くなる に従って陽性率が高くなっているが，各年齢層と も前年齢層と比べ陽性率の差はなかった.しかし， 10歳未満と 10 歳代を比較すると，前者の陽性率が 1.4\%であるのに対して後者のそれが $4.1 \%$ で，有 意差を認めた $(\mathrm{p}<0.025)$.

一方, $\mathrm{HBs}$ 抗体の陽性率は6.6\%で，ここでも 10 歳未満の年齢層では 364 例中 3 例 $(0.8 \%)$ で, 10 代 の陽性率 $10.5 \%$ と比較して有意に低かった（ $<<$ 0.025) (Table 3).
Table 1 Prevalence of $\mathrm{HBs} \mathrm{Ag}$ and anti-HBs in pregnant women in Okinawa island

\begin{tabular}{lcrr}
\hline Age & No. Tested & $\begin{array}{c}\text { HBs Ag } \\
\text { positive(\%) }\end{array}$ & $\begin{array}{r}\text { anti-HBs } \\
\text { positive(\%) }\end{array}$ \\
\hline $15 \sim 19$ & 123 & $1(0.8)$ & $15(12.2)$ \\
$20 \sim 24$ & 681 & $20(2.9)$ & $103(15.1)$ \\
$25 \sim 29$ & 856 & $34(4.0)$ & $195(22.8)$ \\
$30 \sim 34$ & 534 & $21(3.9)$ & $155(29.0)$ \\
$35 \sim 39$ & 120 & $1(0.8)$ & $43(35.8)$ \\
$40 \sim$ & 29 & $1(3.4)$ & $8(27.6)$ \\
\hline Total & 2343 & $78(3.3)$ & $519(22.2)$ \\
\hline
\end{tabular}

Table 2 Prevalence of $\mathrm{HBe} \mathrm{Ag}$ and anti-HBe among $\mathrm{HBV}$ carrier pregnant women in Okinawa island

\begin{tabular}{lccc}
\hline Age & No. Tested & $\begin{array}{c}\mathrm{HBe} \mathrm{Ag} \\
\text { positive(\%) }\end{array}$ & $\begin{array}{c}\text { anti-HBe } \\
\text { positive(\%) }\end{array}$ \\
\hline $20 \sim 24$ & 17 & 0 & $14(82.4)$ \\
$25 \sim 29$ & 28 & $4(14.3)$ & $20(71.4)$ \\
$30 \sim 34$ & 17 & 0 & $16(94.1)$ \\
$35 \sim$ & 2 & 0 & $2(100)$ \\
\hline Total & 64 & $4(6.3)$ & $52(81.3)$ \\
\hline
\end{tabular}

C. キャリアの母親の HBs 抗原, 抗体

今回発見されたキャリアのらち29例の母親が 調査された. 表中の年齢は発端者であるキャリ アの年齢を示す. HBs 抗原陽性例は 29 例中 7 例 (24.1\%)であった（Table 4).

D. キャリアに抢ける $\mathrm{HBe}$ 抗原・抗体

今回の調查で発見された $\mathrm{HBe}$ 抗原陽性者のう ち, HBe 抗原, 抗体を検索できたのは265例で，う

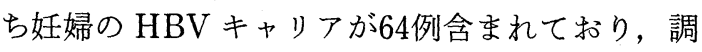


Table 3 Prevalence of HBs Ag anti HBs in Young

People in Okinawa island

\begin{tabular}{|c|c|c|c|c|c|c|c|}
\hline \multirow{3}{*}{$\frac{\text { Age }}{0 \sim 4}$} & \multirow{3}{*}{$\begin{array}{c}\text { Sex } \\
M \\
F\end{array}$} & \multicolumn{2}{|c|}{$\begin{array}{l}\text { No. } \\
\text { Tested }\end{array}$} & \multicolumn{2}{|c|}{$\begin{array}{r}\text { HBs Ag positive } \\
(\%)\end{array}$} & \multicolumn{2}{|c|}{$\begin{array}{r}\text { anti-HBs positive } \\
(\%)\end{array}$} \\
\hline & & 99 & 23 & $2(2.0)$ & 3 & 0 & \\
\hline & & 132 & & $1(0.8)$ & & $1(0.8)$ & \\
\hline \multirow{2}{*}{$5 \sim 9$} & M & 81 & \multirow{2}{*}{133} & 1(1.2) & \multirow{2}{*}{$2(1.5)$} & $2(2.5)$ & \multirow{2}{*}{$2(1.5)$} \\
\hline & $\mathrm{F}$ & 52 & & $1(1.9)$ & & 0 & \\
\hline \multirow{2}{*}{$10 \sim 9$} & M & 180 & \multirow{2}{*}{364} & $3(1.7)$ & \multirow{2}{*}{$5(1.4)^{*}$} & $2(1.1)$ & \multirow{2}{*}{$3(0.8)^{*}$} \\
\hline & $\mathrm{F}$ & 184 & & $2(1.1)$ & & $1(0.5)$ & \\
\hline \multirow{2}{*}{$10 \sim 14$} & M & 52 & \multirow{2}{*}{115} & $1(1.9)$ & \multirow{2}{*}{$4(3.5)$} & $5(9.6)$ & \multirow{2}{*}{$9(7.8)$} \\
\hline & $F$ & 63 & & $3(4.7)$ & & $4(6.3)$ & \\
\hline \multirow{2}{*}{$15 \sim 19$} & M & 172 & \multirow{2}{*}{433} & $8(4.7)$ & \multirow{2}{*}{$18(4.2)$} & $21(12)$ & \multirow{2}{*}{$48(11.1)$} \\
\hline & $\mathrm{F}$ & 261 & & $10(3.8)$ & & $27(10)$ & \\
\hline \multirow{2}{*}{$10 \sim 19$} & M & 224 & \multirow{2}{*}{548} & $9(4.0)$ & \multirow{2}{*}{$\left.22(4.0)^{*}\right]$} & $26(12)$ & \multirow{2}{*}{$\left.57(10.4)^{*}\right\rfloor$} \\
\hline & $\mathrm{F}$ & 324 & & $13(4.0)$ & & $31(9.6)$ & \\
\hline \multirow{2}{*}{ Total } & M & 404 & \multirow{2}{*}{912} & $12(3.0)$ & \multirow{2}{*}{$27(3.0)$} & $28(6.9)$ & \multirow{2}{*}{$60(6.6)$} \\
\hline & $\mathrm{F}$ & 508 & & $15(3.0)$ & & $32(6.3)$ & \\
\hline
\end{tabular}

* : statistically significant

Table 4 Prevalence of $\mathrm{HBs} \mathrm{Ag}$ and anti-HBs in the mothers of $\mathrm{HBV}$ carrier

\begin{tabular}{cccc}
\hline Age & No. Tested & $\begin{array}{c}\text { HBs Ag } \\
\text { positive(\%) }\end{array}$ & $\begin{array}{c}\text { anti-HBs } \\
\text { positive(\%) }\end{array}$ \\
\hline $0 \sim 9$ & 2 & 0 & 0 \\
$10 \sim 19$ & 6 & $1(16.7)$ & $3(50.0)$ \\
$20 \sim 29$ & 10 & $2(20.0)$ & $7(70.0)$ \\
$30 \sim 39$ & 6 & $3(50.0)$ & $2(33.0)$ \\
$40 \sim$ & 5 & $1(20.0)$ & $1(20.0)$ \\
\hline Total & 29 & $7(24.1)$ & $13(44.8)$ \\
\hline
\end{tabular}

査対象が女性に片寄りすぎている傾向にあるが, 全体で34例（12.8\%）が HBe 抗原陽性で，207例 （78.1\%）が HBe 抗体陽性者であった.

年齢階級別にみると，10歳未満では 6 例が全例 とも $\mathrm{HBe}$ 抗原陽性で, 年齢が高くなるに従い逆 に陽性率が低くなって拈り, 30歳以上では127例中 わずか 2 例に $\mathrm{HBe}$ 抗原を認めるのみであった。 10 代の後半と 20 代前半の $\mathrm{HBe}$ 抗原陽性率に差を 認めた $(\mathrm{p}<0.05)$.

一方, $\mathrm{HBe}$ 抗体の陽性率は加龄とともに高くな り，30歳以上では $90 \%$ 以が $\mathrm{HBe}$ 抗体陽性で あった。しかし，どの年齢層も前年齢層との間に 陽性率の差を認めなかった。（Table 5).

\section{考案}

沖縄県の $\mathrm{HBV}$ 保有率は高く, 日本赤十字血液
Table 5 Prevalence of $\mathrm{HBe} \mathrm{Ag}$ and anti-HBe among asymptomatic carriers of $\mathrm{HBV}$ in Okinawa Prefecture

\begin{tabular}{|c|c|c|c|c|c|c|c|}
\hline \multirow{3}{*}{$\frac{\text { Age }}{0 \sim 9}$} & \multirow{3}{*}{$\begin{array}{c}\text { Sex } \\
M \\
F\end{array}$} & \multicolumn{2}{|c|}{$\begin{array}{c}\text { No. } \\
\text { Tasted. }\end{array}$} & \multicolumn{2}{|c|}{$\begin{array}{c}\mathrm{HBe} \mathrm{Ag} \\
\text { positive(\%) }\end{array}$} & \multicolumn{2}{|c|}{$\begin{array}{c}\text { anti-HBe } \\
\text { positive(\%) }\end{array}$} \\
\hline & & 3 & 6 & $3(100)$ & $6(100)$ & 0 & 0 \\
\hline & & 3 & & $3(100)$ & & 0 & \\
\hline \multirow{2}{*}{$10 \sim 14$} & M & 4 & \multirow{2}{*}{10} & $2(50.0)$ & \multirow{2}{*}{$6(60.0)$} & $2(50.0)$ & \multirow{2}{*}{$3(30.0)$} \\
\hline & $\mathrm{F}$ & 6 & & $4(66.7)$ & & $1(16.7)$ & \\
\hline \multirow{2}{*}{$15 \sim 19$} & M & 17 & \multirow{2}{*}{19} & $7(41.2)$ & \multirow{2}{*}{$8(42.1)^{*}$} & $10(58.8)$ & \multirow{2}{*}{$10(52.6)$} \\
\hline & $\mathrm{F}$ & 2 & & $1(50.0)$ & & 0 & \\
\hline \multirow{2}{*}{$20 \sim 24$} & M & 5 & \multirow{2}{*}{41} & $1(20.0)$ & \multirow{2}{*}{$6(14.6)^{*}$} & $4(80.0)$ & \multirow{2}{*}{$30(73.2)$} \\
\hline & $\mathrm{F}$ & 36 & & $5(13.9)$ & & $26(72.2)$ & \\
\hline \multirow{2}{*}{$25 \sim 29$} & M & 9 & \multirow{2}{*}{62} & 2(22.2) & \multirow{2}{*}{$6(9.7)$} & $6(66.7)$ & \multirow{2}{*}{$48(77.4)$} \\
\hline & $\mathrm{F}$ & 53 & & $4(7.5)$ & & $42(79.2)$ & \\
\hline \multirow{2}{*}{$30 \sim 39$} & M & 22 & \multirow{2}{*}{62} & $1(4.5)$ & \multirow{2}{*}{$1(1.6)$} & $20(90.9)$ & \multirow{2}{*}{$56(90.3$} \\
\hline & $\mathrm{F}$ & 40 & & 0 & & $36(90.0)$ & \\
\hline \multirow{2}{*}{$40 \sim 49$} & M & 8 & \multirow{2}{*}{22} & 0 & \multirow{2}{*}{0} & $7(87.5)$ & \multirow{2}{*}{$21(95.5)$} \\
\hline & $\mathrm{F}$ & 14 & & 0 & & $14(100)$ & \\
\hline \multirow{2}{*}{$50 \sim$} & M & 18 & \multirow{2}{*}{43} & 0 & \multirow{2}{*}{$1(2.3)$} & $15(83.3)$ & \multirow{2}{*}{$39(90.7)$} \\
\hline & $\mathrm{F}$ & 25 & & $1(4.0)$ & & $24(96.0)$ & \\
\hline \multirow{2}{*}{ Total } & M & 86 & \multirow{2}{*}{265} & $16(18.6)$ & \multirow{2}{*}{$34(12.8)$} & $64(74.4)$ & $207(78,1)$ \\
\hline & $\mathrm{F}$ & 179 & & $18(10.1)$ & & $143(79.9)$ & \\
\hline
\end{tabular}

*statistically significant

Fig. 2 Change of HBsAg positive rate by year

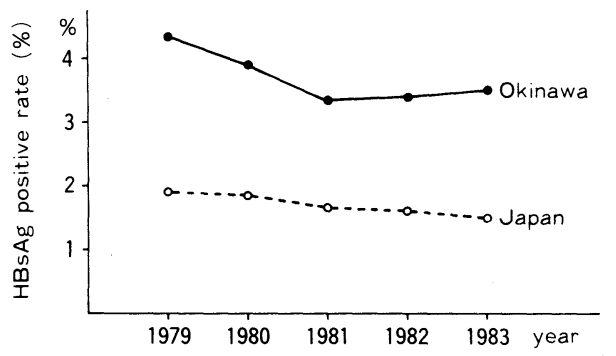

センターの最近 5 年間の調査によると，いずれの 年度も全国平均の 2 倍以上の陽性率を示し全国一 である（沖縄県赤十字血液センターより提供を受 けた日本赤十字社血液事業部集計)。また, HBs 抗 体の陽性率に関しても原ら ${ }^{3)}$, 柏木ら ${ }^{4)}$ の調査によ ると全国平均より明らかに高い陽性率を示し, 沖 縄県が HBV の浸地域であったことがうかがえる (Fig. 2).

そこで我々は沖縄県の母児間感染ならびに水平 感染の現状を把握する目的で前述の調査を実施し た。 
まず母児間感染に関しては, 妊婦に打祆る HBs 抗原陽性率が $3.3 \%$ であり，全国の $1 \sim 2 \%$ ) と比 較して明らかに高い.しかし, キャリア妊婦に括け る $\mathrm{HBe}$ 抗原陽性率は6.3\%で，全国の $20 \sim 30 \%{ }^{5)}$ と比較するとかなり低い成績であった。以上より， 全出産数に対する $\mathrm{HBe}$ 抗原陽性妊婦の出産数は むしろ全国平均より低いものと推定された。

$\mathrm{HBe}$ 抗原, 抗体系は感染性の指標之され, 垂直 感染に扣いても $\mathrm{HBe}$ 抗原陽性の母親から生まれ た児は高率（80～90\%）にキャリアに移行するこ とが知られて捛り, HBワクチン, HBIGによる母 児間感染予防の対象となっている。また, 逆に母 親が $\mathrm{HBe}$ 抗体陽性であればその子供はキャリア 化することはないとされている2). 故に現在, 沖縄 県のキャリア妊婦に抢ける母児間感染の頻度は本 邦の他の報告と比較して明らかに低く, 全出産数 に対する比率においても，母児間感染対策の対象 となる览の出産は全国平均より低率であると推定 された。これらの調査結果を裏づけるように，10 歳未満の年齢層において, HBs 抗原陽性率の減少 を認めた。 また HBs 抗体も同時に低率となって 打り, これらの年齢層に打ける垂直感染, 水平感 染はともに減少しているものと思われた。

低年齢層に拈ける HBV 感染の減少は他の地域

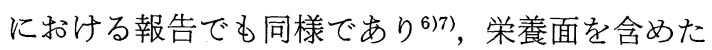
生活環境の向上，注射針に和けるディスポーザブ ルの使用などが原因として上げられている8

次に過去に打ける母児間感染，拈よび水平感染 の実態を推測する意味で，今回発見されたキャリ アの母親の HBs 抗原, 抗体を調査した。 その結果, 29例中 7 例 (24.1\%) が HBs 抗原陽性であった。 また, 沖縄県に拈いて全国と比較して HBV 保 有率が特に高いと思われる10代，20代344の母親で は，その $18.8 \%$ が HBs 抗原陽性であり，この年齢 層のキャリアの約 $80 \%$ は水平感染によるものと想 像された，以上のことょり，これら10代，20代の 年齢層ではその $20 \%$ が垂直感染によって成立した キャリアであり，その年齢層の HBs 抗原陽性率 が母親の世代（40代，50代）よりも高いことによ り, その母親の世代の出産時年齢におけるキャリ ア妊婦の $\mathrm{HBe}$ 抗原陽性率は $20 \%$ より高いものと
Fig. 3 Prevalence of HBe Ag in Tokyo and Okinawa

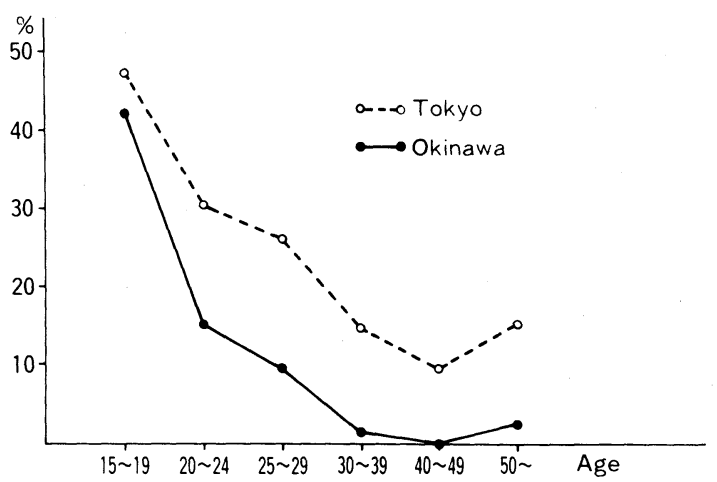

推定された。

$\mathrm{HBe}$ 抗原, 抗体系のもら一つの重要な臨床的意 義として，その肝炎の活動性との関連が上げられ る $^{910)}$. HBe 抗原が持続的に陽性であれば肝障害 が進行しやすく, 慢性肝炎, 肝硬変, 肝細胞癌と いら経過をたどりやすい.一方, HBe 抗体を獲得 すれば肝炎の活動性は鎮静化され, 肝障害の進行 も停止するとされている ${ }^{11)}$. ゆ艺若い時期に

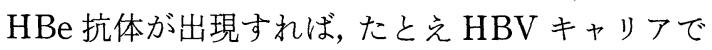
あっても健康人としての生活を送ることが可能 で，事実大部分のキャリアが無症候のまま終始す る.

今回調査された 265 例のキャリアに损いて, その $\mathrm{HBe}$ 抗原陽性率は妊婦に沶ける成績と同様 $13 \%$ と低率であり，ことに30歳以上のキャリアは它と んど90\%がすでに seroconversion していた。また $\mathrm{HBe}$ 抗原消失の時期も10代後半の年齢層で高頻 度に認められ，大林ら ${ }^{12)}$ の報告した成績よりも若 い世代に移行していた。

Fig. 3は沖縄県のキャリアに打ける $\mathrm{HBe}$ 抗原 陽性率の年齢別の推移を東京都のキャリア・クリ ニック (献血時 $\mathrm{HBs}$ 抗原が検出された例 $)^{13)}$ に打 けるそれと比較したものである。図からも明らか なように20歳以上の $\mathrm{HBe}$ 抗原陽性率を比較する と, 沖縄県は東京都の $1 / 2$ 以下の陽性率であり, 東 京都のキャリアに打いては30歳以上でも依然とし て $10 \%$ 前後の $\mathrm{HBe}$ 抗原陽性者が認められるのに 対して，沖縄県では匡とんど認められない。これ らの結果より，沖縄県に捻いてはHBVによる慢 
Table 6 Proteinic intake and HBV carrier rate by country

\begin{tabular}{lccc}
\hline & HBV carrier rate & Protein intake & Year of investigation \\
\hline Papua New Guinea & $18.0 \%$ & 20 & 1971 \\
Philipines & 16.0 & 45.8 & 1969 \\
Thailand & 9.8 & 49.1 & 1972 \\
\hline Taiwan & 6.3 & 72.0 & 1971 \\
China & 4.5 & 58.2 & 1966 \\
Japan & 2.7 & 78.7 & 1976 \\
\hline USA & 0.3 & 93.7 & 1966 \\
Great Britain & & 88.6 & 1966 \\
France & 0.1 & 98.2 & 1966 \\
\hline
\end{tabular}

Fig. 4 Change of mortality rate (liver cirrhosis) by year

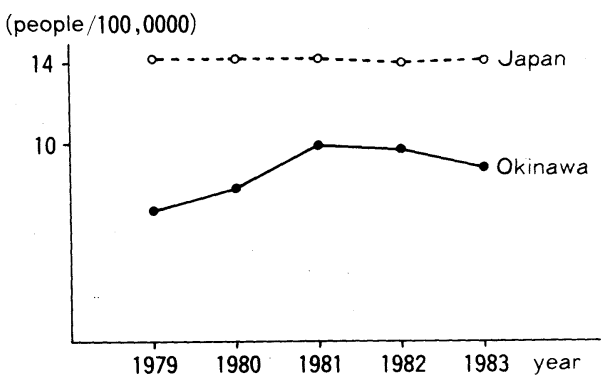

性肝疾患が少ないものと推定された。

Fig. 4 に最近 5 年間の慢性肝疾患ならびに肝硬 変死亡率の年次推移を示すが，図から女明らかな ように, 沖縄県の肝硬変死亡率は全国平均と比較 してかなり低率である。このことは，前述のキャ リアに打ける $\mathrm{HBe}$ 抗原が早期にしかも高率に消 失するといら成績と関連するように思われるが, 肝硬変全体における HBV の関与はせいぜい $30 \%$ 程度 ${ }^{14)}$ であり，他の要因の検討も合わせて行う必 要があるかと思われた。

以上のように沖縄県のキャリアにおいて $\mathrm{HBe}$ 抗原, 抗体系の seroconversion が高率に起ってい る原因何なのであろらか.

西岡は各国の HBV 保有率と各国民の蛋白摂取 量が逆相関するといら調査成績より, HBウイル スの排除が栄養の影響をらけているのではないか と推定している (Table 6) ${ }^{15)}$. 事実, 蛋白摂取量 の高い欧米のキャリア妊婦に括ける $\mathrm{HBe}$ 抗原陽 性率は日本や東南アジアに比べ低率であり, HBV
Fig. 5 Change of nutritional intake by year

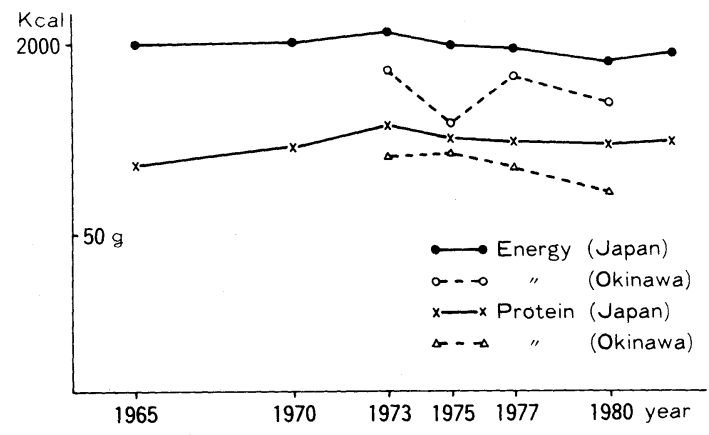

保有率も $1 \%$ 以下である5). また，棟久ら ${ }^{16)}$ は，肝 癌多発地域である長崎県の富江町住民の栄養摂取 量は蛋白を含めて低率であったと報告している。

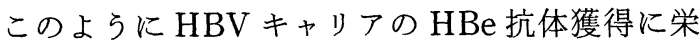
養摂取, 特に蛋白の摂取が何らかの影響を与えて いるものと推定される.

Fig. 5は沖縄県の総エネルギーと蛋白摂取量の 年次推移を全国と比較した成績である。沖縄県に 関しては復帰後の1972年から調查が開始されてお りそれ以前の比較はできないが，総エネルギー， 蛋白ともに全国を下回っていた，次に，沖縄県に おいて総エネルギーに対する割合の特に高かった 脂肪と動物性蛋白の摂取量を比較すると，前者は 全国平均より若干高い傾向にあるが，後者はむし ろ低率であった（Fig. 6).

このように栄湌摂取の面からは, 沖縄県のキャ リアにおける seroconversionの現状を説明でさ ないよらであった，今後さらに多方面からの解析 により,キャリアに护を seroconversionを促進 
Fig. 6 Change of nutritional intake by year

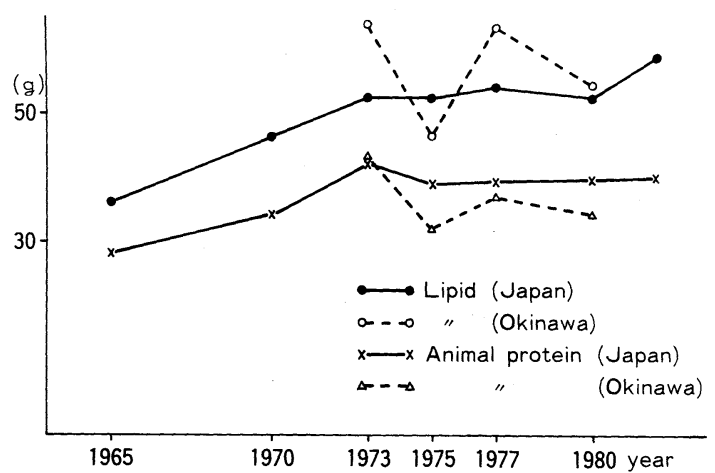

する要因を解明する必要があると思われた。

\section{結語}

沖縄県の妊婦に拈ける HBV 保有率は全国平均 の約 2 倍であるが，キャリア妊婦の $\mathrm{HBe}$ 抗原陽 性率は明らかに低く, 全出産数に対する垂直感染 の数は全国平均より低いものと推定された。 また， これを裏づけるように, 低年齢層に打いて感染の 減少を認めた。

さらに,キャリアに和ける seroconversion が若 い世代に，しかも高率に起って扣り, HBVによる 慢性肝疾患は少ないものと推定された。

稿を終えるに臨み, 本調査に御協力を賜った沖縄県石川 保健所の粟国成也氏, 那覇保健所の安谷屋ヨシ子氏, なら びに中央保健所の安富祖忠章氏, および東京都臨床医学総 合研究所の皆様に深謝いたします。

尚本論文の要旨は第59回日本感染症学会総会に打いて発 表した。

\section{文献}

1) Magnius, L.O. \& Espmark, J.A.: New specificity in Australia antigen positive sera distinct from Le Bouvier Determinants. J. Immun., 109: 1017-1021, 1972.

2) Okada, K., Kamiyama, I., Inomata, M., Imai, M., Miyakawa, Y. \& Mayumi, M. : e-antigen and anti-e in the serum of asymptomatic carrie mothers as indicators of positive and negative transmission of hepatitis $B$ virus to their infants. New Engl. J. Med., 294 : 746-749, 1976.

3）原実, 粟国成也, 安谷屋ヨシ子, 中村徹雄, 馬場 清, 津田文男：沖縄県に打ける A 型, B 型 肝炎ウイルス感染について。日本公衛誌, $29: 591$ -592, 1981.

4) 柏木征三郎, 林純, 新安世三, 林田一男, 加 地正郎：B 型肝炎の伝播様式について一キャリア 調查よりの考察一日本医事新報, $2982: 21-26$, 1981.

5）白木和夫：B 型肝炎垂直感染予防に関する国際力 ソファランス. 肝胆膵, $2(5): 667-679,1981$.

6）松下 寛：ウイルス肝炎の疫学. B 型肝炎. 治療, 66: 1533-1539, 1984.

7) 羽金已与之, 鬼澤 信，市村登寿ら：栃木県に打 ける小児 HB ウイルス感染の疫学調查. 小児科診 療, 48: 1097-1099, 1985.

8）西岡久壽彌：肝炎ウイルス感染症の現況. 公衆衛 生, $47: 207-212,1983$.

9）中村正憲, 大河内一雄, 古賀俊一, 入佐俊武, 井 林 博：肝疾患に拈ける e 抗原および $\mathrm{e}$ 抗体の臨 床的研究. 肝臓, 18: 540-547, 1977 .

10）赤羽賢浩, 清沢研道, 真弓 忠5：HBs 抗原陽性 肝疾患抢よび無症候性 HBs 抗原 carrier に打け る $\mathrm{HBe}$ 抗原抗体系. 第 2 編. 経過観察症例に扣壮 る $\mathrm{HBe}$ 抗原抗体の臨床的意義. 肝臓, $21: 391$ $-400,1980$.

11）飯野四郎：HBe 抗原 - 抗体. 肝胆傘, $8: 51-88$, 1984.

12）大林 明, 松尾雄二, 真弓 忠ら : e 抗原・抗体に 関する疫学的研究一無症状 HBsAg キャリアに特 ける e 抗原, 抗 $\mathrm{e}$ 抗体の年齢別出現頻度と感染性 に関する考察一。肝臓, $17: 741-746,1976$.

13）飯野四郎：キャリア対策：1つの試み. 厚生省肝 炎連絡協議会, 昭和 57 年度研究報告, 72-76, 1982 .

14）太田康幸, 原田 尚編：肝硬変の成因々予後. 南 江堂, 東京, 1984 .

15）西岡久壽彌：栄養と生体防衛。輸液・栄養ジャ一 ナル, 2: 229-234, 1980.

16）棟久龍夫, 楠本征夫, 長龍重信ら：肝癌・肝硬変 多発地域 (五島富江町) 住民の栄養摂取状況之慢 性肝疾患との関連に関する一考察。日消誌，80： $828-836,1983$. 
Epidemiological Studies on Hepatitis Be Antigen and Antibody in Okinawa

Hiroshi SAKUGAWA, Keizo KADENA, Tominori OYAKAWA, Masaaki UEHARA, Tamiki ARAKAKI, Fukunori KINJO \& Kazumine KOBARI

First Department of Internal Medicine, Faculty of Medicine, School of Medicine, University of the Ryukyus

The examination of sera for HBs antigen and HBs antibody were carried out on 2343 pregnant women in Chubu district, Okinawa during the period of the years 1982 and 1983. HBs antigen was found in 78 sera $(3.3 \%)$ of examinees. Further serological studies for HBe antigen and HBe antibody were performed on 64 cases among HBs positive pregnant women. HBe antigen was positive in four cases $(6.3 \%)$ out of them and $\mathrm{HBe}$ antibody positive in $52(81.1 \%)$.

The serological investigations for HBs antigen and HBs antibody on 912 healthy young people in Okinawa showed that in the age group of 0 to 9 years old, the positive rate of HBs antigen was $1.4 \%$ and HBs antibody $0.8 \%$, respectively. From the result it is presumed that recently vertical infection with $\mathrm{HBV}$ seems to be reducing and subsequently HBV carrier rate in the lower age group is decreasing.

In the serological investigations for HBe antigen and HBe antibody on 265 asymptomatic HBs antigen carriers (including 64 pregnant women), HBe antigen was positive in 34 cases (13\%) and $\mathrm{HBe}$ antibody in 207 cases $(78 \%)$, respectively. In the comparison of positive rate by the age group as $0-9$, $10-14,15-19,20-24,25-29$ and over than 30 years old, the positive rate of $\mathrm{HBe}$ antigen was $100 \%$ in youngest group and declined gradually as the age group become older, in the age group over than 30 years old only two positive cases were found among $127 \mathrm{HBs}$ antigen carrriers. 